University of Euroregional Economy in Jozefow, Poland

\title{
LEGAL PROTECTION OF THE CULTURAL IDENTITY OF A PERSON IN POSTMODERN EUROPE
}

\begin{abstract}
A characteristic feature of post-modernity is the atomization of society while at the same time far-reaching globalization processes takes place. In this context, one of the most important human rights is the need to define and protect its identity. The atomization of society is a consequence of the break-up of the family as well as traditional social structures such as the state, religious communities and trade unions. This phenomenon is accompanied by frequent changes of location. The concept of small homelands disappears. Globalization provides a person with a range of technical and electronic instruments that on the one hand make life easier and on the other hand pose a threat to people. Social media facilitate communication, but at the same time increase the threat to the protection privacy and sensitive data. The subject of the study will be the assessment of the legal framework for the protection of human identity against atomization and globalization processes in the European Union and the presentation of possible new solutions in this field.
\end{abstract}

KEYWORDS: identity, globalization, post-modernity, atomization of society, international law, the law of the European Union.

\section{INTRODUCTION}

The right to identity is one of the most important human rights. The issue of identity is the subject of statements of many politicians and many scientific or media studies. It is recognized that European identity is a valuable value that needs to be protected (Identity ..., 2015). It is characteristic, however, 
that the use of this term is often intuitive, because it is indeed an ambiguous concept. This notion is often understood by the recipient intuitively and sometimes without any reflection.

According to the Oxford philosophical dictionary, the term identity belongs to the original relational expressions. Otherwise, one can say that it is the identity of indistinguishable objects (Blackburn, 1994, p. 407). Literature distinguishes different types of identities, including social, personal, cultural, regional, national or even Internet identity. Among the different types of identity, the most important seems to be the cultural one. Such a hypothesis is due to the growing immigration from the Middle East to Europe. As a result, there is a mix of cultures, a revival of nationalism, or simply the loss of the European autochthon and the newcomer about the value system, dresses, family shape pr work style (Novikova, 2018, p. 41 n, Benedict, 1966, p. 565-568).

This new situation is reflected in the acts of international law in which there are normative provisions regarding the protection of identity, especially the cultural one, and consequently regional, national, social and personal.

\section{POST-MODERNITY - A NEW ERA IN THE HISTORY OF HUMANKIND}

Christoph Keller (Cellarius 1638-1707) from the University of Halle proposed the division of the world's history into three epochs: antiquity, the Middle Ages and modern times (Cellarius, 1753). With time, the epoch called the newest times was added. The important events in the history of humankind are the justification for this division. It is assumed that antiquity ended with the fall of the Western Empire, in 475. The end of the Middle Ages dates back to 1453 - the fall of Constantinople, as well as to the discovery of America by Columbus in 1492 (a change in the concept of the current world) and to the invention of printing by Gutenberg in 1450 (books became widely available). The newest times were initiated by the outbreak of the First World War, in 1914.

The passage of time, as well as political and social changes, including cultural, as well as technical and technological changes, give impetus to scientific reflection aimed at building a theorem on the entry of humanity into 
a new period of history. These changes are called globalization processes and as a result of which the world becomes one "global village" in which everyone can know everything. Another characteristic feature of this period is the growing migration of people from the poor south to the rich north of our globe. This leads to profound changes in the existing culture and reference elements so important for identity (Petrilli, 2008, pp. 51-62). Today, it is no longer surprising that the minister of national defence of Canada is Harjit Sajjan, a Sikhish-born Indian. He is also not neglected wearing the outfit typical for believers of this religion, while at the same time fulfilling one of the most important ministerial offices in Canada - the country with a different culture.

A characteristic feature of the first and second decade of the third millennium is relativism, or rejection of metaphysical concepts and values developed over the centuries. This leads to the denial of the possibility of learning the absolute truth and searching for credible cognitive methods even in the sciences. No one is building big philosophical systems like G.W. Hegel (1770-1831) or I. Kant (1724-1084). The possibility of learning about legal rules and order in the world is increasingly denied (Izdebski, 2011, p. 43, Baran, 2003, Perkowska, 2003). Far-reaching technization and economization of science, even social sciences and humanities, are being carried out. On the other hand, the concept of political correctness is being built together with a public critique apparatus for those who would vote on views that are different from the dominant ones. The tolerance of views closes within a narrow layer of commercialized values, thus contributing to the radicalization of the behaviour of social groups that proclaim different views, from those that are in the mainstream of political correctness.

The attempts to define this new era have been made in literature for a long time. According to the Polish and American philosopher Z. Bauman, this is the period of so-called "Liquid modernity". In this way, he defined the phenomenality of processes occurring in the postmodernist era, such as the multi-centricity of philosophy or legal systems, isolating individual cases from the whole, for example - the isolating a specific legal solution from the entire legal system or isolating the event, from the sequence of events (context), relativity of behaviour, and consequently, the relativism of ethical or moral standards (Izdebski, 2011, pp. 43 and 63). 
Another term used to designate the present era in the history of humankind is the philosophical concept of "post-modernity" (Izdebski, 2011, pp. 43 and 63), which was used, among others, by M. Heidegger (1889-1976) (Heidegger, 2004, p. 3). It emphasizes the relationships that occur between people and phenomena caused by globalization processes. As a result, the modern local and international organizational structures are being transformed. This is the same as the model of an industrial society based on large factories. This phenomenon is accompanied by a loss of faith in progress, and the phenomenon of crisis and risk is becoming more frequent. Trends such as consumerism, moral relativism, extreme individualism, the development of mass culture, the emergence of new religions, network communities and the rise of social inequalities are intensifying. In addition, a new phenomenon is the emergence of an information society based on knowledge and innovation. In the end, there is no single center monopolizing certain knowledge, truth, law. Even the Catholic Church, until now the most centralized institution of the last centuries in the world, is gradually subject to the process of disintegration.

The terms "postmodernism" and "liquid modernity" are supplemented by other terms, such as „rapid-fire culture", "culture of acceleration”, "late modernity", "hyper- modernity" or "reflexive modernity" (Krajewska, 2012, s. 94). Many thinkers, however, deny such far-reaching conclusions about the ongoing cultural changes, which have their origins in the second half of the twentieth century. Among others, M. Lipowicz says: This brings us to the core of post-modernity: the departure from the centralized structure of being, which, in the cultural order determined the framework of the individual human existence, means the disintegration of the ontological sense of security. But this is by no means the end: instead of trying to restore or compensate the past security by some equivalents for metaphysical concepts, the postmodern thinking sees, in this socio-cultural change, "the opportunity" for the discovery of new forms of life, experience, and thinking. (...) These rules may apply to both the arts and the most basic aspects of social life, such as family life, policy, economics, etc. From this point of view, the fundamental - customs, moral and religious changes of the West become understandable: they are not simply an expression of some progress, as it was naively claimed in modernity (progress 
of what?). The contemporary disintegration of traditional structures is not a conscious act of Westerners, but a structural consequence of decentralization of culture (Lipowicz, 2014, pp. 131-132).

\section{CULTURAL IDENTITY OF EUROPE IN POSTMODERNISM}

Europe operates in the context of the post-modern world with its problems and benefits. The relativization of the value system and social, economic and political changes create a number of problems regarding European identity both in the dimension of individual states and the entire European Union (Sitek, 2015, pp. 111-126).

Cultural identity includes the process of identifying individual people, but also groups of people with a specific cultural system consisting of a set of ideas, beliefs, customs, beliefs, and often a common language. Common language, however, is not a sine qua non condition of a common culture. An example here is Russian culture, where different languages are used locally in Russia. It is similar in China or in India. Even in Italy, local dialects are so different that people living in nearby towns do not understand themselves.

This identity is built on a specific normative and axiological system in order to strengthen the internal unity of the group. An individual may belong to different social groups functioning within the same group or belonging to different cultures. In the first case, there is the phenomenon of strengthening the cultural affiliation. In the second case, the cultural affiliation is weakened.

The cultural identity requires its consolidation by nurturing a common history and its symbols. The culture of every community is born in a space of certain time. It is very similar with European culture. It is assumed that the beginnings of European culture started with the fall of the western part of the Roman Empire in 475. This is the beginning of a certain integration of peoples living or arriving on the territory of the European continent. This process is clearly opposed to the culture of ancient Rome, which was created within the framework of a country that included territories belonging to three different continents. The cultural diversity, including various languages was the characteristics of this Empire. The population living under the rule of Roman emperors were basically connected by one power, the same 
citizenship, one tax system and one legal system, but not necessarily and not always. However, the far-reaching ideological and religious tolerance was a characteristic feature of that period. As the territorial expansion continued, the empire began to weaken. One of the important reasons was the lack of cultural identity of Roman habitants or citizens.

The consolidation of peoples living exclusively on the territory of Europe began with the collapse of the Western Empire. The creation of the Carolingian state, which gained significant development during the reign of Charlemagne was the moment of breakthrough. Undoubtedly, it was helpful in this process to refer to the idea of recreating the Roman Empire, which caused Charles the Great to be anointed by Pope Leo III on the Emperor Sacrum Imperum Romanum. The whole identity of medieval Europe was built on the basis of Christianity with significant elements of the Roman culture (especially Roman law), the Greek philosophy and Judaism (the shape of the family). The system of Christian values was reflected in architecture, art, ideals, symbols, aisles of cities, lifestyle, clothing, science and politics. During this period, despite heresy (Waldenses or Cathars), Europe was quite strongly culturally united. All those who were outside Europe or did not accept this culture were referred to as infidel or barbarians (Neumann, 1999, p. 39). These people were led to a policy of civilization, evangelization and conversion. These activities were experienced by the socalled pagan peoples, including Prussians and Yajvings.

This fairly cohesive European culture survived properly until the colonization of Asia, Africa and South America. Such a long period of functioning of the ethos of the medieval European culture survived despite the far-reaching internal changes that the trends of Renaissance brought with them. One should point first of all to the emerging liberal philosophies (J. Lock, A. Smith, J.-J. Rousseau, F.-M. Wolter) and to the legal positivism (J. Austin, R. von Jhering, G. Jelinek, H. Hart and H. Kelsen). There were also changes in the perception of religion and its role in social and cultural life. F.-M. Voltaire rejected the authorities, and proclaimed, instead, the tolerance for a variety of different and often contradictory attitudes. He perceived religion as a source of intolerance and restriction of freedom. He, thus, favoured the desacralization of social, cultural and political life 
initiated by the French revolution. The criticism of the view that Christianity is a foundation or element that unites European culture has begun.

According to I.B. Neumann, an important moment for the formation of European cultural identity was the recognition in 1856 on the basis of the Treaty of Paris (Treaty of Peace and Friendship) of the Ottoman Empire as part of the system of power in Europe. Thus, the possibility of departing from building the cultural cohesion of Europe on the basis of Christianity in favour of such value as peace and social order was allowed. This event had quite a significant impact on the perception of Europe and o the perception of the identity of politics with a tradition in which the Muslim state could not be found. The European identity had to give way to political interests or collective interests (Neumann, 1999, p. 39). Thus, the cross ceased to be a European symbol.

The colonies set up by European countries in Asia (England, France, Portugal), Africa (England, the Netherlands, Belgium, France, Germany), South America (England, France, Spain) and North America (Spain, Portugal) have also contributed to the deepening of the processes of departing from the medieval identity of Europe. The colonies were established for the exploration of natural resources, but also to obtain the cheap labour for Europe. The mass import of people from Asia, Africa and South America to Europe started already in the 17 th century. As a result, the representatives of various groups with different cultural identities collided with each other and the creation of a multicultural society in Europe has begun (Dammacco, 2004, pp. 29-38). Today, the representatives of various religions live alongside each other, such as Christians, Muslims, Hindus, Jews and non-believers. There are also numerous religious sects. The Christians themselves are divided into Catholics, Protestants and Orthodox Christians. In addition, new ideologies emerged in the nineteenth and twentieth century as part of socialist or nationalist thought.

The migration process of people from outside Europe has intensified in the $20^{\text {th }}$ and $21^{\text {st }}$ centuries. It is undoubtedly a continuation of the processes initiated by the eighteenth and nineteenth century colonies. Consequently, the current European identity and culture is mixed with the culture of Islam and people of African or Asian descent. The citizens of continents who are 
culturally different are immigrating to Europe to search the better conditions for existence. They settle in European countries and become part of their society, but without integration with European culture. They retain their own identity brought from their countries of origin. What is more, the increasingly numerous representation of these national minorities sits in the parliaments of European countries, for example in the parliament of the United Kingdom currently sits 13 Muslims (Ahmed-Sheikh, 2015). In France, 5 Muslims entered parliament in 2012. And in the French governments, there are people from former French colonies. Muslims and representatives of other cultures are quite often represented in the European Parliament. They demand respect for their rights, different from European culture, for example - in the Great Britain, they postulate the legalization of polygamy. The population of the Muslim religion is also growing. In France, it is 7.50 people, in Belgium and in the Netherlands 6\%. Belgium also introduced legal regulations that prevent the local elections being won by radical Muslim groups. These provisions were introduced after the situation when the registered Muslim party set itself the goal of introducing the Sharia law in Belgium.

The weakening of the European identity also proceeds in the light of the expansion of Asian and Arab capital. This capital comes into quite important sectors of the economy for European countries, such as: transport, especially aviation (the expansion of the Emirates airline), health care, road construction and even sport. The concluding a three-year sponsorship agreement between Real Madrid and the National Bank of Abu Dhabi was quite a significant event. As a result, "The Royal" removed the cross from the old coat of arms (Owczarek, 2014). The symbol and element of the European identity has lost with great money, which is undoubtedly followed by great Cultural Revolution coming from the Middle East to Europe.

Mixing different cultures is not only a typical feature of globalism or the postmodern days. This phenomenon has been accompanying humanity since the beginning. In fact, the history of humankind is the history of migration, the rise of civilization and its fall. In this changing world, however, the individual is looking for permanent elements, such as identity, that is, identifying him or herself with some system of values, history, people, place, architecture, etc. The average person wants to have a similar environment. Then, a sense of 
certainty is born in him or her. Meanwhile, the current period of European history does not give this sense of certainty. It is a time of cultural conflicts (Szymaniak, 2007, pp. 326-341).

One of the visible signs of this conflict is the concept of secularism of the state. In France, the ban on wearing religious symbols was introduced on this canvas, which, however, is strictly enforced against Christian symbols. In the face of other religions, this prohibition is applied extremely tolerant (Kowalczewska, 2012, p. 81 n.). At the same time, the resistance to these changes is being resurrected in many countries, and the political events in Hungary, Slovakia, the Czech Republic and Poland are the examples this resistance. Similar movements are also born in the extremely tolerant countries such as France, Belgium, the Netherlands and Great Britain (Roman, 2016, p. 369 n.).

A chance to get out of this rather difficult situation is perhaps what the European Union proposes. The striving for the unification of Europe that began after the Second World War has already laid some foundations for a new reality that may be the environment for the birth of a new European identity. The European Union, or previously the European Communities, has endeavoured to not only to achieve political, economic and defence goals, but also to build a common cultural base.

\section{LEGAL FRAMEWORK FOR IDENTITY PROTECTION}

The European Union is an international sui generis organization with an unspecified goal. All the time there are ongoing disputes over the final shape of this organization - rather it should be one strong state or a loose federation (Barcik, A. Wentkowska, 2008, pp. 33-35). Recent experience, resulting from the internal disputes between Member States regarding immigrants and the exit of the United Kingdom from the Union, shows that this goal is even more unclear and more distant. Until now, the Union remains a platform for the single market, a space of free movement of citizens of the Member States, enhanced cooperation of police services to guarantee security within the EU borders. Other specific Union objectives are set out in the article 2 TEU and in the consolidated Treaty on the functioning of the European Union, we do not talk about the objectives but about the scope of activity and competences of the European Union (the articles 3 and 4 TFEU) (Grosse, 2008, pp. 1-30). 
However, the basic question that should be asked at this stage of consideration is: does the current European Union have any elements that create the European identity? If so, what are the symbols and how are they accepted? And finally, are they a source of pride for the citizens of the Union, as it is the case in the USA, for example?

The existence of the European Communities or now the European Union for over 60 years has undoubtedly created a common policy regarding the shape of European identity. This problem was a fairly widely discussed issue in 2004, during the ratification of the Treaty establishing a Constitution for Europe by the individual EU Member States. Ultimately, this document was not adopted in 2005 by the most liberal states, namely France and the Netherlands, precisely because it did not correspond to the European system of values or the ethos of European identity.

However, the paradox of all this discussion was that this document managed to achieve a certain compromise between the ideologically distant environments. In the preamble to this document, it was concluded: CONVINCED that, while remaining proud of their own national identities and history, the peoples of Europe are determined to transcend their former divisions and, united ever more closely, to forge a common destiny... This wording clearly indicated the far-reaching tolerance and the will to preserve national identity and history, while taking measures to alleviate or abolish the former divisions in Europe accumulated over the centuries. In the article I-5 was declared to preserve and respect national identity, which meant no more or less that national identity would not be liquidated as a result of the growing European identity.

The issue of the status of religions and churches was quite a significant element of the discussion, but also the divisions within the European Union. At that time, there were fears that the Constitution for Europe would be an opportunity to significantly reduce religion in public life. Hence in the article I-52 of the Constitution for Europe decided to leave the question of the status of churches in the sphere of jurisdiction of the Member States, without closing the dialogue with religions at the EU forum. The most important statement, however, was that the Union recognizes the contribution of these churches to culture and European identity. In this way, the European or Union identity includes philosophical currents such as: traditional (Kaff, Lehr, 1990, 
pp. 171-190), liberal (Frommelt, 1990, pp. 191-207), federal t (Brickwedde, 1990, p. 208-221) and social trends (Blumenberg-Lampe, F. Bohm, 1990, pp. 234-247). Besides, the churches themselves, especially the Catholic ones, for long time, have been proposing and showing great willingness to cooperate with EU organizations in the area of relations with the authorities of the Member States and EU bodies also regarding their participation in building the vision of the future Europe (Gulvan, 1991, pp. 26-30).

Despite existing disputes about the role of the European Union, its shape and objectives, one can point to the EU symbols, which are undoubtedly elements of European identity. Their existence also indicates the emergence of social awareness in this area. These symbols are: the flag, the hymn, the common currency (euro) and the Europe Day. These symbols have not found their place in the treaty law. Member States have only recognized and respected them on the basis of the declaration attached to the consolidated Treaty on the functioning of the European Union (Declaration No. 52).

The European Union flag is the basic and commonly found in Europe and in the world symbol of the European Union. Few people know that it is also a symbol of the Council of Europe. The origins of this symbol date back to 1950, when the Council of Europe announced a competition to design the European flag. The competition was won by Arsèna Heitz, an employee of the Council of Europe postal service. This flag has a blue colour with a circle of twelve golden stars. The author himself, before the death, clearly declared that the inspiration for this project was a vision of the end of the world described in the Apocalypse by Saint John the Apostle. The symbol of this vision was the Mother of God on the background of the blue sky and a wreath of twelve golden stars rested on her head. In 1983, the European Parliament supported the recognition of the flag of the Council of Europe as well as the flags of European Communities. Eventually, this flag in 1986 hung in front of the seat of the European Commission. This flag is now also the EU flag, despite the fact that the Treaty of Lisbon does not provide any symbols of the European Union. Currently, the EU flag, next to the US flag, is the most recognizable flag in the world.

The second symbol of the European Union is the hymn "Ode to Joy" from the 9th Ludwig van Beethoven Symphony. Also in this case, the initiative to 
accept Ode as the anthem of Europe came from the Parliamentary Assembly of the Council of Europe in 1971. A year later, it was accepted by the Council of Ministers of the Council of Europe. The European Community in 1986 adopted Ode as its own hymn. Consequently, in 1993, the European Union did the same. The music composed by the great composer does not raise doubts. Doubts are gathered around the text written by Frederic Schiller. Some argue that this text contains a reference to general values, not just European ones. Another unresolved issue is the language in which the official version of the hymn is to be sung. One of the proposals is to make it Latin. As a dead language, he should not be in doubt.

The third and quite important symbol of the Union is a common currency - the euro. Its role is analogous to the American dollar, recognized and exchanged all over the world. The EU is also striving to ensure that its currency has a good position in the global monetary system, but also to be pride of Europeans. The beginning of activities related to the creation of the common currency goes back to the 1960s with the intensifying European integration. In 1970, P. Werner worked out the idea of a European monetary union. Despite the fact that this project was not implemented, however, he began very specific work on the creation of the common currency. The final decision to establish the common currency was made at the Maastricht Summit in 1992, together with the idea of building the European Union. At that time, convergence criteria were introduced, such as the price stability, the excessive deficit procedure, the European exchange rate mechanism and the interest rates. The accusation to the monetary union was possible when a given country met the requirements of convergence. Finally, the euro in cash form was introduced in 2002 (Martinelli 2017, pp. 244-246).

In the so-called Euro-zone, there are currently $19 \mathrm{EU}$ countries. There are some EU's countries, including Poland, which are outside the Eurozone. This symbol of EU or European identity raises a number of fears resulting mainly from economic motives. The introduction of the euro even in such rich countries as Germany caused a significant increase in prices, often by 100 percent. The ordinary citizen suffered damage in this case. The economic value sometimes prevails over cultural values and symbols. Somewhat, the euro is a symbol that links the European Union, including 
those that are outside the euro area. In general, the problem of currency conversion and losses on this operation has disappeared.

The last symbol of European identity and unity is the so-called Europe Day celebrated annually on $9^{\text {th }}$ May. Also in this case, this Day was established by the Council of Europe. His celebration was scheduled for $5^{\text {th }} \mathrm{Ma}$, the day of the creation of the Council of Europe. In the intention of its creators, the content of this symbol is to be tolerance, human rights and European integration. In turn, in the European Union, this day is sometimes called the Day of the European Union and is celebrated annually on $9^{\text {th }}$ May. Ultimately, in the European Union we celebrate the Europe Day. The date of $9^{\text {th }}$ May refers to the anniversary of the presentation of the plan to create a European Coal and Steel Community, the so-called Schuman's plan.

\section{CONCLUSIONS FOR THE FUTURE}

The concept of a united Europe is born in the environment of large ethnic resistance. It gives rise to many forms of social or political dissent towards the processes of European integration, which, unfortunately, are growing. Among the various objections posed against the current concept or vision of this new Europe, there are the threat of denationalization, the loss of tradition and, consequently, the loss of cultural identity. It is this cultural identity that is the main hotspot for current discussions, disputes and emerging centrifugal tendencies. The fact is the fear of losing identity begins to dominate quite strongly.

These fears have their source, among others, in the policies of the 1980s and later, when European socialists came to power. For the long-time, the Left, led by the mission of carrying out the torch of education and freeing people from religious or superstitious ignorance, quite unequivocally ignored different views and pushed the believers and their Christian identity on the margin of social life. As a consequence, strong philosophical trends or even political parties of a national character began to emerge in order to defend the national identity. Today, these parties come to power in some EU countries, which may threaten the further existence of the European Union.

Meanwhile, the European Union which has been created up on the basis of the European Communities already has a certain tradition and it is essentially 
grown in the spirit of Christian doctrine. The great creators of this idea, for example: Alcide de Gasperi, Kondrat Adenauer and Robert Schuman were Christians, and their beatification processes are under the way. They warned against the creation of Europe as an ideological community. Europe should be economically and politically strong. For the future of a united Europe, it is therefore necessary to move away from the creation of an ideological European unity. This postulate is justified by the fact that post-modernity itself creates far-reaching changes in culture. This is influenced by the growing economic immigration to Europe of people from other cultures.

It is enough to pay attention to the existing European symbols, such as the flag, the national anthem, the celebration of Europe Day and the respect for the common currency. These values, above all, should be under the legal protection in the system of the EU law and the law of individual member states. Currently, such legal protection did not exist. These values are constant and immutable despite the globalization processes taking place in post-modern Europe. It has always been the case that the course of history has automatically introduced changes in the content of culture, despite the existing fixed points of reference. It is possible to create such a model of European identity, especially since there are very solid foundations for this. This is possible for example in the USA, where everyone can ponder the culture of their country of origin and, at the same time, cultivate values common to all Americans. The same was in ancient Rome, so eagerly followed by the Americans. Maybe it is worth to create the behaviour of standing in position at attention not only during national anthems, but also during the European Union anthem, and the EU flag should be in every home.

\section{References:}

Ahmed-Sheikh, T. (2015). Rekordowa liczba muzulmanów w brytyjskim parlamencie, Online text: http://euroislam.pl/rekordowa-liczba-muzulmanow-w-brytyjskimparlamencie/ [access: 2018-07-05].

Baran, B. (2003). Postmodernizm i końce wieku, Kraków: Wyd. Inter Esse. ISBN 8389-44801-7.

Barcik, J. Wentkowska A. (2008). Prawo Unii Europejskiej z uwzględnieniem Traktatu z Lizbony, Warszawa: Wyd. C.H. Beck. ISBN 978-83-255027-37. 
Bauman, Z. (2006). Płynna nowoczesność, przekład T. Kunz, Kraków: Wyd. Literackie. ISBN 83-08-03847-6.

Benedict, R. (1996). Relatywizm kulturowy, In: A. Mencwel, Antropologia kultury. Zagadnienia i wybór tekstów, Warszawa, p. 565-568; : Wyd. UW. ISBN. 83-2350078-9.

Blackburn, S. (1994). Oksfordzki słownik filozoficzny, tłum. polskie, Warszawa, s.v. tożsamość, p. 407: Wyd. Książka i wiedza. ISBN 83-05-12920-9.

Blumenberg-Lampe, Ch. Bohm, F. (1981). Die Konzeption der Sozialen Marktwirtschaft, In: Buchstab G., Gotto K. Die Gründung der Union. Traditionen, Entstehung und Repräsentanten, München, pp. 234-247: Wyd. Olzog. ISBN 97837-7892716-49.

Brickwedde, F. Muller J. (1990). Die förderliche Tradition, In: G. Buchstab, K. Gotto, Die Gründung der Union. Traditionen, Entstehung und Repräsentanten, München, pp. 208-221: Wyd. Olzog. ISBN 978-37-7892716-49.

Cellarius, Ch. (1753). Historia universalis breviter ac perspicve exposita, in antiquam, et mediiaevi ac novam divisa, cum notis perpetuis, Altenbvrgi.

Dammacco, G. (2004). Il diritto alla identità nel multiculturalismo Europea, [in:] B. Sitek i inni (re.), Człowiek a tożsamość w procesie integracji Europy, Olsztyn, pp. 29-38: Wyd. UWM. ISBN 83-7299-324-6.

Frommelt, R. (1990). Die liberale Tradition, In: G. Buchstab, K. Gotto, Die Gründung der Union. Traditionen, Entstehung und Repräsentanten, München, pp. 191-207: Wyd. Olzog. ISBN 978-37-7892716-49.

Galvan, S. (1991). Pluralismo culturale e dialogo, In: G. Dal Ferro, S. Fontana, M.V. Nodari, le regioni del Nord-Est. Società, economia e ambiente, Padova, pp. 26-30 : Wyd. EMP. ISBN 88-25000-642.

Grosse, T.G. (2008). Hybrydowy ustrój Unii Europejskiej. Dwie logiki zmian w projekcie traktatu konstytucyjnego, Analizy Natolińskie 3(26), pp. 1-30. Online text: http:// www.natolin.com.pl/pdf/analizy/Natolin_Analiza_3_2008.pdf [access: 2016-03-20].

Heidegger, M. (2004). Bycie i czas, tłum. B. Baran, Warszawa: Wyd. PWN. ISBN. 978-83-011622-07.

Izdebski, H. (2011). Elementy teorii i filozofii prawa, Warszawa: Wyd. LexisNexis, ISBN 978-83-762091-66.

Kaff, B. Lehr, R. (1990). Die konservative Tradition, In: G. Buchstab, K. Gotto, Die Gründung der Union. Traditionen, Entstehung und Repräsentanten, München, pp. 171-190: Wyd. Olzog. ISBN 978-37-7892716-49. 
Kowalczewska, K. (2012). Prawo szariatu i jego kompatybilność z europejskim systemem ochrony praw człowieka [in:] M. Marcinko (re.), Ochrona praw człowieka w wymiarze regionalnym, Kraków, pp. 81-90: Wyd. WPiA UJ. ISBN 83-915947-2-6.

Krajewska, A. (2012). Niebezpieczeństwa szybkostrzelnej kultury obrazu w okresie dzieciństwa, Journal of Modern Science, no 3/14, pp. 94-102. ISSN 1734-2031.

Lipowicz, M. (2014). Problem z „ponowoczesnościa”: pusty spór formalny czy zmiana charakteru egzystencji ludzkiej? Analiza i egzystencja nr 26, pp. 131.-132. ISSN 1734-9923.

Martinelli, F. (2017). Manuale di diritto dell'Europa. Aspetti istituzionali e politiche dell'unione, Napoli: Wyd. Simone. ISBN 9788891413963.

Neumann, I.B. (1999). Uses of the Other: The" East" in European Identity Formation. Manchester: Wyd. University Minnesota. ISBN. 9780816630837.

Novikowa, K. (2018). Jednostka w społeczeństwie: procesy samoidentyfikacji w świetle wspótczesnych koncepcji tożsamości, Journal of Modern Science no 1/36, pp. 41-66. ISSN 1734-2031.

Owczarek, M. (2014). Real Madryt z herbem bez krzyża. Dla arabskiego sponsora, Online text: http://www.sport.pl/pilka/1,65082,17035059,Real_Madryt_z_ herbem_bez_krzyza_Dla_arabskiego_sponsora.html [access: 2018-07-05].

Perkowska, H. (2003). Postmodernizm a metafizyka, Warszawa 2003: Wyd. Scholar. ISBN 837383009X.

Petrilli, S. (2008). Nation, identity, and global communication. A semiotic approach, In: A. Ponzio (ed.), Globalizzazione e infunzionalità, Roma, pp. 51-62: Wyd. Meltemi. ISBN 978-88-8353-683-0.

Roman, Ł. (2016). Rzeczywistość kryzysu we wspótczesnych uwarunkowaniach polityczno-militarnych, Journal of Modern Science nr 1/28, pp. 369-388. ISSN 1734-2031.

Sitek, M. (2015). Tożsamość narodowa (europejska) a obywatelstwo Unii Europejskiej, Journal of Modern Science nr 4/27, pp.111-126. ISSN 1734-2031.

Szymaniak, A. (2007).Jakośćżycia w wielokulturowejEuropie. Rozważanianapodstawie francuskiego zakazu noszenia symboli manifestujących przynależność religijna, [in:] B. Sitek i inni (re.), Prawo do życia a jakość życia w wielokulturowej Europie, v. 2, Olsztyn-Bari, pp. 326-341: Wyd. ISBN 978-83-89112-23-1.

Tożsamość jako cena trwania w Unii Europejskiej? (2015). Online text: https:// obserwatorpolityczny.pl/?p=35067 [access: 2016-03-20]. 